\title{
Motivasi Belajar Siswa SMA pada Pembelajaran Daring di Masa Pandemi Covid-19
}

\author{
Adhetya Cahyani ${ }^{1}$, Iin Diah Listiana ${ }^{2}$, Sari Puteri Deta Larasati ${ }^{3}$ \\ ${ }^{1}$ Pascasarjana, Universitas Islam Negeri Sunan Kalijaga Yogyakarta, Indonesia \\ ${ }^{2}$ Pascasarjana, Universitas Islam Negeri Sunan Kalijaga Yogyakarta, Indonesia \\ ${ }^{3}$ Pascasarjana, Universitas Islam Negeri Sunan Kalijaga Yogyakarta, Indonesia \\ ${ }^{1}$ adhetyacahyani@gmail.com \\ 2iindiahlistiana24@gmail.com \\ ${ }^{3}$ sariputridetalarasati@gmail.com
}

\begin{abstract}
Abstrak:
Sistem pendidikan di Indonesia sedang mengalami tantangan baru yang disebabkan karena adanya wabah virus Covid-19, yang menyebabkan seluruh sistem pembelajaran di lembaga pendidikan dialihkan kepada metode pembelajaran online atau dalam jaringan (daring). Adanya gangguan dalam proses pembelajaran menyebabkan terjadinya beberapa perubahan terhadap peserta didik yang pada akhirnya berpengaruh terhadap motivasi belajarnya. Penelitian ini menggunakan pendekatan kuantitatif, dengan teknik sampling yang digunakan adalah accidental sampling. Populasi dalam penelitian ini adalah seluruh siswa SMA yang mengikuti proses pembelajaran dengan sistem online atau daring. Metode analisis yang digunakan untuk menganalisis data yang diperoleh dalam penelitian ini menggunakan metode analisis Mann Whitney $U$. Jenis penelitian ini menggunakan landasan teori motivasi belajar dan aspek-aspek dari teori Chernis \& Goleman (2011). Hasil penelitian ini menunjukkan bahwa nilai siginifikansi Mann Whitney $U$ sebesar 0,000 yang artinya motivasi belajar pada siswa yang mengikuti pembelajaran daring atau online di tengah situasi pandemik virus Covid-19 ini menurun, karena nilai signifikansi yaitu 0,000 adalah kurang dari 0,05 ( $\mathrm{p}<0,05)$.
\end{abstract}

Kata Kunci: Pembelajaran Daring, Motivasi Belajar, Siswa SMA, Pandemi Covid-19

\begin{abstract}
:
Education system in Indonesia is experiencing new challenges due to the Covid-19 virus outbreak, which has caused the entire learning system in educational institutions to be transferred to online learning methods. The disruption in the learning process causes some changes to students which ultimately affect the motivation to learn. This research uses a quantitative approach, with the sampling technique used is accidental sampling. The population in this study were all high school students who took part in the process online learning. The analytical method used to analyze the data obtained in this study uses the Mann Whitney U analysis method. This type of research uses the foundation of learning motivation theory and aspects from Chernis \& Goleman's theory (2011). The results of this study indicate that the significance value of Mann Whitney $\mathrm{U}$ is 0,000 which means the motivation to learn in students
\end{abstract}


who take online or online learning in the midst of the pandemic situation of the Covid-19 virus is decreasing, because the significance value of 0,000 is less than $0.05(\mathrm{p}<0,05)$.

Keywords: Online Learning, Learning Motivation, High School Student, Covid-19 Pandemic

\section{Pendahuluan}

Pendidikan adalah sebuah usaha yang dilakukan oleh individu secara sadar dan terencana untuk mewujudkan proses pembelajaran yang efektif dengan tujuan mendidik peserta didik dalam mengembangkan potensi dirinya. ${ }^{1}$ Namun dewasa ini, masih banyak sekali permasalahan-permasalahan di dalam dunia pendidikan yang dapat menghalangi tercapainya tujuan-tujuan yang diharapkan.

Permasalahan di dalam pendidikan tersebut merupakan prioritas utama yang harus dipecahkan, salah satunya menyangkut tentang masalah kualitas pendidikan. Kualitas pendidikan saat ini tengah mengalami tantangan sebagai dampak mewabahnya virus Covid-19. Covid-19 menjadi pandemik global yang penyebarannya begitu menghawatirkan. Akibatnya pemerintah harus bekerja sama untuk menekan laju penyebaran virus Covid-19 dengan mengeluarkan kebijakan agar seluruh warga masyarakat untuk melakukan social distancing atau menjaga jarak. ${ }^{2}$ Sehingga dengan adanya kebijakan tersebut seluruh aktivitas masyarakat yang dulu dilakukan di luar rumah dengan berkumpul dan berkelompok, kini harus diberhentikan sejenak dan diganti dengan beraktivitas di rumah masing-masing.

Salah satu dampak social distancing juga terjadi pada sistem pembelajaran di sekolah. Berdasarkan Surat Edaran Nomor 4 Tahun 2020 tentang Pelaksanaan Kebijakan Pendidikan dalam masa darurat penyebaran virus, Mendikbud menghimbau agar semua lembaga pendidikan tidak melakukan proses belajar mengajar secara langsung atau tatap muka, melainkan harus dilakukan secara tidak langsung atau jarak jauh. ${ }^{3}$ Dengan adanya himbauan tersebut membuat semua lembaga pendidikan mengganti metode pembelajaran yang digunakan yaitu menjadi online atau dalam jaringan (daring).

\footnotetext{
${ }^{1}$ Nurhasanah Nurhayati Dahliana, "Dinamika Motivasi Belajar Pada Siswa Mandiri di SMPN 10 Banda Aceh," Universitas Syiah Kuala 1, no. 2 (2016): 73-79.

2 "Kebijakan 'Social' dan 'Physical Distancing' Harus Libatkan Tokoh Sampai RT/RW," Sekretariat Kabinet Republik Indonesia, diakses 22 April 2020, https://setkab.go.id/kebijakan-social-dan-physical-distancing-haruslibatkan-tokoh-sampai-rt-rw/.

3 "SURAT EDARAN MENDIKBUD NO 4 TAHUN 2020 TENTANG PELAKSANAAN KEBIJAKAN PENDIDIKAN DALAM MASA DARURAT PENYEBARAN CORONA VIRUS DISEASE (COVID- 1 9)," Pusdiklat Pegawai Kementerian Pendidikan dan Kebudayaan, 24 Maret 2020 , https://pusdiklat.kemdikbud.go.id/surat-edaran-mendikbud-no-4-tahun-2020-tentang-pelaksanaan-kebijakanpendidikan-dalam-masa-darurat-penyebaran-corona-virus-disease-covid-1-9/.
} 
Sebenarnya pembelajaran daring ini bukan hal baru bagi Indonesia, model pembelajaran ini telah dikembangkan sejak tahun 2013 sebagai alternatif pembelajaran, artinya sebelum adanya wabah virus ini, Indonesia telah mengaplikasikan metode tersebut. Tetapi tidak semua lembaga yang mengaplikasikan, terutama sekolah-sekolah yang berada di pedesaan. Dengan adanya wabah virus ini, membuat dan mengharuskan seluruh sekolah, perguruan tinggi dan lembaga pendidikan lainnya, menggunakan metode pembelajaran daring tanpa terkecuali, dengan tujuan agar proses pembelajaran tetap berjalan meskipun harus dilakukan di rumah masing-masing.

Keadaan ini tentu saja memberikan dampak pada kualitas pembelajaran, siswa dan guru yang sebelumnya berinteraksi secara langsung dalam ruang kelas sekarang harus berinteraksi dalam ruang virtual yang terbatas. guru dituntut memberikan pengajaran yang baik, menciptakan suasana yang kondusif untuk belajar dan secara kreatif dan inovatif menggunakan media belajar yang menarik agar siswa dapat memahami materi pembelajaran dan tujuan pembelajaran dapat tercapai.

Selain itu, motivasi belajar siswa juga berpengaruh dalam keberhasilan pembelajaran. Hal ini sesuai dengan yang diungkapkan oleh Emda bahwa proses pembelajaran akan mencapai keberhasilan apabila siswa memiliki motivasi belajar yang baik. ${ }^{4}$ Oleh karena itu motivasi belajar sangat penting untuk dimiliki oleh setiap siswa, baik motivasi intrinsik maupun ekstrinsik.

Iklim belajar yang diciptakan pembelajaran daring turut mempengaruhi motivasi belajar siswa, jika dalam pembelajaran luring guru mampu menciptakan suasana kelas kondusif untuk menjaga motivasi belajar siswa agar pembelajaran dapat tercapai karena iklim kelas memiliki pengaruh yang signifikan dengan motivasi belajar. ${ }^{5}$ Namun kondisi pembelajaran daring menyebabkan guru kesulitan untuk mengontrol dan menjaga iklim belajar karena terbatas dalam ruang virtual. Kondisi ini menyebabkan motivasi belajar siswa dapat menurun bahkan mempengaruhi hasil belajar siswa.

Melalui wawancara pra-penelitian yang dilakukan dengan beberapa guru bahwa selama pembelajaran daring, motivasi belajar siswa menurun, hanya sedikit yang berpartisipasi dan aktif dalam pembelajaran. Berdasarkan hasil wawancara, guru menyatakan bahwa selama

\footnotetext{
${ }^{4}$ Amna Emda, "Kedudukan motivasi belajar siswa dalam pembelajaran," Lantanida Journal 5, no. 2 (2018): 181. ${ }^{5}$ Dewi Permata Sari dan A. R. Rusmin, "PENGARUH IKLIM KELAS TERHADAP MOTIVASI BELAJAR PESERTA DIDIK DI SMAN3 TANJUNG RAJA," Jurnal PROFIT Kajian Pendidikan Ekonomi dan Ilmu Ekonomi 5, no. 1 (2018): 80-88.
} 
pembelajaran online diberlakukan untuk semua lembaga pendidikan, banyak mengalami perubahan, salah satunya adalah pada motivasi belajar siswa, terutama pada siswa jenjang SMA. Siswa SMA adalah individu yang memasuki masa remaja, di mana masa remaja sangat rentan mengalami permasalahan karena mengalami perubahan baru dalam dirinya. ${ }^{6}$ Selanjutnya Anna Freud juga berpendapat bahwa perubahan yang terjadi pada masa remaja meliputi perubahan dalam perkembangan psikoseksual dan hubungan dengan cita-cita dan orang tua. Cita-cita dapat terwujud, salah satunya melalui pendidikan ${ }^{7}$. Inilah yang menjadi alasan penulis memilih siswa SMA sebagai subjek dalam penelitian. Selain itu juga, di perkuat oleh pendapat dari beberapa guru SMA, bahwa motivasi belajar siswa SMA memang mengalami penurunan selama situasi pandemik ini.

Penelitian ini bertujuan untuk mencari titik permasalahan yang menjadi kendala, faktorfaktornya serta dampak yang ditimbulkan. Manfaat dari penelitian ini adalah untuk memperkaya khazanah keilmuan dan literasi di bidang pendidikan khususnya pada masa pandemi ini. Dan juga sebagai perpanjangan saran kepada pihak-pihak akademisi dan dinas pendidikan yang masih terus berupaya memperbaiki sistem pendidikan di Indonesia khususnya.

Maka dari itu, penulis tertarik untuk menindaklanjuti permasalahan tersebut dengan tujuan untuk untuk mengetahui apakah motivasi belajar siswa SMA menurun atau meningkat selama pembelajaran daring di tengah situasi pandemik Covid-19.

\section{Motivasi Belajar}

Motivasi belajar adalah variabel yang terdiri dari dua kata yaitu motivasi dan belajar, yang keduanya memiliki arti tersendiri. Jika membahas mengenai motivasi, sering kali disandingkan dengan kata motif. Sesuai dengan penelusuran peneliti, motif dapat diartikan sebagai gerak atau sesuatu yang mendorong individu untuk bergerak. ${ }^{8}$ Sedangkan motivasi, menurut Mc Donald adalah suatu perubahan energi yang terjadi pada individu yang ditandai dengan timbulnya perasaan dan reaksi atau tindakan untuk mencapai tujuan tertentu. ${ }^{9}$ Sedangkan belajar menurut Slameto adalah suatu proses usaha untuk mendapatkan perubahan pada tingkah laku. ${ }^{10}$ Dengan demikian yang dimaksud dengan motivasi belajar adalah keseluruhan daya penggerak yang terletak di dalam diri peserta didik yang memunculkan niat

\footnotetext{
${ }^{6}$ John W. Santrock, "Perkembangan Pendidikan,” (Jakarta: Erlangga, 2003).

${ }^{7}$ Emda, "Kedudukan motivasi belajar siswa dalam pembelajaran,".

${ }^{8}$ Peter Salim dan Yenny Salim, Kamus Besar Bahasa Indonesia Kontemporer (Jakarta: Modern English, 1991). 997.

${ }^{9}$ Syaiful Bahri Djamarah, Psikologi Belajar (Jakarta: Rineka CIpta, 2002). 114.

${ }^{10}$ Syaiful Bahri Djamarah. 13.
} 
untuk melakukan kegiatan belajar, sehingga tujuan yang dikehendaki oleh subjek belajar itu dapat tercapai.

\section{Aspek-Aspek Motivasi Belajar}

Menurut Marilyn K. Gowing ada empat poin aspek-aspek motivasi belajar, adapun penjelasannya sebagai berikut: ${ }^{11}$

a. Dorongan Mencapai Sesuatu

Peserta didik merasa terdorong untuk berjuang demi mewujudkan keinginan dan harapan-harapannya.

b. Komitmen

Komitmen adalah salah satu aspek yang cukup penting dalam proses belajar. Dengan memiliki komitmen yang tinggi, peserta didik memiliki kesadaran untuk belajar, mampu mengerjakan tugas dan mampu menyeimbangkan tugas.

c. Inisiatif

Peserta didik dituntut untuk memunculkan inisiatif-inisiatif atau ide-ide baru yang akan menunjang keberhasilan dan kesuksesannya dalam menyelesaikan proses pendidikannya, karena ia telah mengerti dan bahkan memahami dirinya sendiri, sehingga ia dapat menuntun dirinya sendiri untuk melakukan hal-hal yang bermanfaat bagi dirinya dan juga orang di sekitarnya.

d. Optimis

Sikap gigih, tidak menyerah dalam mengejar tujuan dan selalu percaya bahwa tantangan selalu ada, tetapi setiap dari kita memiliki potensi untuk berkembang dan bertumbuh lebih baik lagi.

Kemudian aspek-aspek motivasi belajar menurut Frandsen yaitu :

a. Memiliki rasa ingin tahu yang besar terhadap hal baru. Oleh karena itu, selalu terdorong untuk belajar, demi mengejar cita-citanya.

b. Kreatif, peserta didik terus berpikir dan menciptakan sesuatu yang baru, sehingga membuat dirinya berbeda dengan yang lainnya.

\footnotetext{
${ }^{11}$ Marilyn K. Gowing "Measurement of Individual Emotional Competence” dalam Daniel Goleman, Cary Cherniss (ed.). The emotionally intelligent workplace: How to select for, measure, and improve emotional intelligence in individuals, groups, and organizations. (Fransisco: Jossey-Bass, 2001) 88.
} 
c. Menginginkan simpati dari orang tua, guru dan teman-temannya. Sebagai manusia biasa, kita menginginkan suatu pujian sebagai bentuk penghargaan terhadap apa yang telah kita lakukan maupun kita capai.

d. Memperbaiki kegagalan yang lalu dengan usaha yang baru. Tidak menutup kemungkinan, ketika kegagalan menghampiri kita, pasti terbesik rasa kecewa, tetapi bukan berarti membuat kita putus asa dan menyerah, melainkan harus terus berjuang demi menjemput kesuksesan kita.

e. Merasa aman ketika telah menguasai materi pelajaran.

f. Memberlakukan ganjaran atau hukuman sebagai akhir dari belajar. Setiap dari kita pasti telah mengetahui dan percaya bahwa ketika melakukan hal yang baik, akan mendapatkan hasil yang baik pula, begitu pun sebaliknya. Dengan memiliki pemikiran seperti ini, akan memicu peserta didik untuk terus semangat dalam belajar.

Aspek-aspek di atas merupakan bagian dari sekian banyak pendorong agar peserta didik memiliki keinginan untuk belajar, karena apabila peserta didik memiliki dorongan seperti aspek-aspek di atas, maka peserta didik tersebut akan mendapatkan hasil yang maksimal sesuai dengan harapannya.

\section{Faktor-Faktor yang Mempengaruhi Motivasi Belajar}

a. Faktor Internal ${ }^{12}$

1. Cita-cita dan Aspirasi

Salah satu faktor pendukung yang dapat memperkuat semangat dalam belajar adalah dengan memiliki cita-cita. Sedangkan aspirasi adalah sebuah harapan atau keinginan yang dimiliki oleh individu dan selalu menjadi tujuan dari perjuangan yang telah ia mulai.

2. Kemampuan Peserta Didik

Motivasi belajar dipengaruhi oleh setiap kemampuan yang dimiliki oleh peserta didik. Kemampuan yang dimaksud adalah segala potensi yang dimiliki baik itu dari segi intelektual maupun psikomotorik.

3. Kondisi Peserta Didik

Kondisi secara fisiologis juga turut mempengaruhi motivasi belajar peserta didik. Seperti kesehatan dan panca indera. Ketika peserta didik memiliki kesehatan dan

\footnotetext{
${ }^{12}$ E-book, Motivasi Belajar, http://eprints.uny.ac.id/8469/ Diakses pada 10 Mei 2020
} 
panca inderanya dapat bekerja secara maksimal, peserta didik telah memiliki peluang untuk mencapai keberhasilan dalam proses pendidikannya.

4. Keadaan psikologis peserta didik yang mempengaruhi motivasi belajar yaitu :

a) Bakat

Bakat adalah kemampuan yang dimiliki oleh setiap individu yang apabila terus diasah dan dikembangkan melalui belajar akan menjadi sebuah kecakapan dan sangat membantu untuk meraih kesuksesan.

b) Intelegensi

Inteligensi dapat diartikan sebagai kemampuan psikofisik dalam mereaksikan rangsangan atau menyesuaikan diri dengan lingkungan melalui cara yang tepat. Inteligensi bukan selalu berkaitan dengan otak, tetapi adanya interaksi dan koneksi antar organ-organ yang ada di dalam tubuh manusia.

c) Sikap

Sikap juga memiliki peran penting dalam mempengaruhi motivasi belajar peserta didik. Artinya ketika peserta didik belajar dalam keadaan atau suasana senang, cara guru dalam mengajar yang baik dan sebagainya akan membuat peserta didik semangat sehingga memperoleh hasil yang maksimal, begitu pun sebaliknya.

d) Persepsi

Persepsi peserta didik tentang belajar, manfaatnya dan keuntungan yang didapatkan ketika belajar juga mempengaruhi kemauannya untuk terus belajar.

e) Minat

Salah satu hal yang memiliki pengaruh yang besar dalam motivasi belajar adalah minat. Ketika peserta didik memiliki minat yang besar terhadap pelajaran matematika, ia akan belajar dengan sungguh-sungguh dan sebaik-baiknya. Begitu pun dengan pelajaran yang lainnya.

f) Unsur-Unsur Dinamis dalam Pembelajaraan

Perasaan, ingatan, keinginan dan pengalaman yang dimiliki peserta didik turut mempengaruhi motivasi dalam belajar, baik itu secara langsung maupun tidak langsung. 


\section{b. Faktor Eksternal}

Faktor eksternal berarti faktor-faktor di luar dari diri peserta didik yang ikut berperan dalam mempengaruhi motivasi belajar. Diantaranya : (1) Kondisi lingkungan belajar, kondisi lingkungan belajar yang kondusif akan mendukung dan memperkuat semangat belajar peserta didik. (2) Lingkungan sosial sekolah, seperti guru, teman-teman di kelas dapat mempengaruhi proses belajar. (3) Lingkungan sosial masyarakat, ketika peserta didik merasa diakui keberadaanya dengan diikutsertakan dalam kegiatan masyarakat, juga akan mempengaruhi semangatnya dalam belajar. (4) Lingkungan sosial keluarga, hubungan antar orangtua dan anak yang harmonis dan saling menghargai juga akan mempengaruhi motivasi anak dalam belajar. (5) Lingkungan non sosial, terbagi dua yaitu lingkungan alamiah dan faktor instrumental. Lingkungan alamiah, artinya dukungan, kasih sayang dan kebiasaan-kebiasaan keluarga yang baik akan turut mempengaruhi motivasi belajar anak. Sedangkan faktor instrumental seperti fasilitas atau sarana prasarana yang disediakan oleh sekolah juga akan mempengaruhi semangat peserta didik dalam belajar.

\section{Metode Pembelajaran Daring/Online}

Metode pembelajaran yang berbasis teknologi memiliki banyak penyebutan, seperti online, dalam jaringan (Daring) dan E-Learning. Kesemuanya memiliki makna yang sama, hanya saja konteks penempatan katanya yang sering di pertukar balikkan. E-Learning merupakan suatu sistem pembelajaran yang menggunakan media perangkat elektronik. E-Learning adalah sebuah kegiatan pembelajaran melalui perangkat elektronik komputer yang tersambungkan ke internet, dimana peserta didik berupaya memperoleh bahan belajar yang sesuai dengan kebutuhannya. ${ }^{13}$

E-Learning merupakan sebuah inovasi baru yang memiliki kontribusi sangat besar terhadap perubahan proses pembelajaran, dimana proses belajar tidak lagi hanya mendengarkan uraian materi guru secara langsung tetapi siswa juga melakukan aktivitas lain seperti mengamati, melakukan, mendemonstrasikan dan lain-lain. Materi bahan ajar di visualisasikan dalam berbagai format dan bentuk yang lebih dinamis dan interaktif sehingga siswa akan termotivasi untuk terlibat lebih jauh dalam proses pembelajaran tersebut. ${ }^{14}$ Lebih lanjut Rosenberg menekankan bahwa e-learning merujuk pada penggunaan teknologi internet untuk mengirimkan serangkaian solusi yang dapat meningkatkan pengetahuan dan

\footnotetext{
${ }^{13}$ Syarifudin, "Pengembangan Sistem Pembelajaran Online di SMK NU Unggaran" (2017). Hal. 19

14 "Motivasi Belajar Mahasiswa Terhadap Metode Pembelajaran Online iLearning Pada Perguruan Tinggi," t.t. hlm. 193.
} 
keterampilan. Ada pula yang menafsirkan e-learning sebagai bentuk pendidikan jarak jauh yang dilakukan melalui media internet.

Oleh karena itu berdasarkan pemaparan dari beberapa tokoh mengenai pengertian metode pembelajaran online/daring atau e-learning, penulis menyimpulkan bahwa metode pembelajaran tersebut merupakan salah satu metode yang berbasis elektronik, dilakukan dengan jarak jauh dan dapat memudahkan siswa untuk mencari berbagai informasi yang dibutuhkan untuk menunjang pembelajarannya. Selain itu, metode ini juga memudahkan pendidik atau guru untuk mencari materi-materi yang selengkap mungkin dan dikemas dengan menarik.

\section{Gambaran Pembelajaran Daring/Online/E-Learning}

Salah satu instruksi pemerintah tentang kegiatan yang dilakukan di rumah adalah kegiatan belajar. Belajar tidak boleh berhenti. Kegiatan belajar mengajar (KBM) dipindahkan di rumah, tetapi harus dikendalikan oleh guru atau dosen dan orang tua, dengan menggunakan pembelajaran jarak jauh. Pembelajaran Jarak Jauh ini dilakukan awalnya selama kurang lebih 14 hari, tetapi tidak menutup kemungkinan telah ditambahkan lagi karena melihat situasi dan kondisi perkembangan COVID-19 ini. $^{15}$

Pembelajaran jarak jauh sangat dibutuhkan saat ini oleh semua siswa mulai dari tingkat sekolah dasar hingga perguruan tinggi, dan ini tidak hanya terjadi di Indonesia, bahkan hampir di seluruh dunia melaksanakan pembelajaran dengan E-learning. ${ }^{16}$ Dalam pembelajaran elearning atau online, pelajar dapat berinteraksi langsung dengan konten pembelajaran yang mereka temukan dalam berbagai format seperti, video, audio, dokumen, dan sebagainya. Selain itu, mereka juga dapat memilih untuk mengurutkan pembelajaran mereka sendiri, diarahkan, dan dievaluasi dengan bantuan seorang guru. Interaksi ini dapat terjadi dalam komunitas penyelidikan, menggunakan berbagai aktivitas sinkron dan asinkron berbasis internet (video, audio, konferensi komputer, obrolan, atau interaksi dunia maya). Lingkungan online yang sinkron dan asinkron ini akan mempromosikan pengembangan keterampilan sosial dan kolaboratif, serta hubungan pribadi di antara peserta didik. ${ }^{17}$

\footnotetext{
${ }^{15}$ Zaharah Anissa Windarti Galia Ildusovna Kirilova, "Impact of Corona Virus Outbreak Towards Teaching and Learning Activities In Indonesia," 2020, Jurnal Sosial dan Budaya Syar'i, 07, no. 03 (t.t.): 269-82, https://doi.org/10.15408/sjsbs.v7i3.15104. Hal. 270

16 Anissa Windarti. Hal. 280

${ }^{17}$ Huang Wang, H.H R.H., Liu, D.J., Tlili, A., Yang, J.F., Handbook On Facilitating Flexible Learning, During Educational Disruption: The Chinese Experience In Maintaining Undisrupted Learning in Covid-19 Outbreak, 2020 ed. (Smart Learning Institute of Beijing Normal University, 15). Hal. 10
} 
Berdasarkan kondisi negara kita yang saat ini sedang dilanda virus COVID-19, peran pembelajaran berbasis online sebagai pendukung proses pembelajaran menjadi sangat signifikan dan perlu. Terutama di era global saat ini, transformasi berjalan sangat cepat. Kenyataannya adalah siswa bahkan dapat lebih mudah beradaptasi dengan teknologi baru dan perubahan yang ada saat ini. Penerapan pembelajaran berbasis online untuk pengajaran dan pembelajaran memiliki dua tantangan utama, yaitu: (1) penerapan pembelajaran berbasis online sebagai "alternatif yang sulit bagi siswa"; dan (2) aplikasi berbasis online untuk menghasilkan siswa berpengetahuan (student-based student), yaitu memanfaatkan berbasis online untuk mengembangkan diri secara berkelanjutan (long life learning) dan meningkatkan produktivitas mereka. $^{18}$

Pembelajaran berbasis online atau jarak jauh diharapkan memberi dampak positif pada siswa dan kemajuan pendidikan di Indonesia. Dalam hal ini, guru juga mengharapkan partisipasi dan pengasuhan orang tua di rumah untuk mendorong anak-anak mereka agar semangat belajar di rumah, menggunakan fasilitas yang ada dan melakukan kegiatan sesuai dengan ketetapan pemerintah selama COVID-19. ${ }^{19}$

Sebagai salah satu cara yang dilakukan penulis untuk memperkaya khazanah keilmuan mengenai tema yang diangkat adalah dengan memperbanyak referensi atau rujukan. Referensi tersebut berfungsi untuk memperluas dan memperdalam bahasan mengenai tema penelitian, serta menentukan kelayakan penelitian. ${ }^{20}$ Mengenai hal tersebut, penulis mengambil dua kata kunci penting yaitu, 'motivasi belajar siswa' dan 'metode pembelajaran daring'.

Penelitian terkait motivasi dan peran guru. Penelitian yang dilakukan Andaru Werdayanti yang berjudul "Pengaruh Kompetensi Guru dalam proses Belajar Mengajar di Kelas dan Fasilitas Guru terhadap Motivasi Belajar Siswa”. Jurnal ini mengupas tentang faktor-faktor pengaruh kompetensi guru, penelitian ini menunjukkan bahwa terdapat pengaruh yang cukup signifikan antara kompetensi guru dan fasilitas belajar terhadap motivasi belajar. ${ }^{21}$ Selain itu penelitian yang dilakukan oleh Siti Suprihatin yang berjudul "Upaya Guru dalam Meningkatkan Motivasi Belajar Siswa." Hasil penelitian menunjukkan bahwa berbagai upaya yang dilakukan guru dalam meningkatkan motivasi belajar adalah memperjelas tujuan yang

\footnotetext{
${ }^{18}$ Anissa Windarti, "Impact of Corona Virus Outbreak Towards Teaching and Learning Activities In Indonesia," t.t. Hal. 272

${ }^{19}$ Anissa Windarti, "Impact of Corona Virus Outbreak Towards Teaching and Learning Activities In Indonesia," t.t. Hal. 279

${ }^{20}$ John W. Creswell, Research design: qualitative, quantitative, and mixed methods approaches, 4th ed (Thousand Oaks: SAGE Publications, 2014), 32.

${ }^{21}$ Andaru Werdayanti, "Pengaruh Kompetensi Guru dalam Proses Belajar Mengajar di Kelas dan Fasilitas Guru Terhadap Motivasi Belajar Siswa,” Dinamika Pendidikan 3, no. 1 (2008).
} 
ingin dicapai, membangkitkan motivasi siswa, menciptakan suasana belajar yang menyenangkan, menggunakan variasi metode penyajian yang menarik, memberikan pujian yang wajar disetiap keberhasilan siswa, memberikan penelian, memberikan komentar terhadap hasil pekerjaan siswa dan menciptakan persaingan dan kerjasama. ${ }^{22}$

Kemudian, penelitian terkait motivasi dan lingkungan belajar. Penelitian yang dilakukan oleh Dewi permata sari, dkk yang berjudul "Pengaruh iklim kelas terhadap motivasi peserta didik di SMAN 3 Tanjung Raya" yang dianalisis dengan teknik regresi linear sederhana menunjukkan hasil bahwa terdapat pengaruh yang cukup signifikan antara iklim kelas dengan motivasi belajar siswa sehingga guru diharapkan mampu menciptakan suasana kelas yang kondusif agar tujuan pembelajaran dapat tercapai. ${ }^{23}$ Itto Nesyia Nasution juga meneliti kedua variabel di atas di tempat yang berbeda yang memiliki hasil yang juga sama bahwa memang terdapat korelasi yang positif antara iklim kelas dengan motivasi belajar peserta didik. ${ }^{24}$

Sedangkan penelitian terkait motivasi dan hasil belajar. Penelitian yang dilakukan oleh Hendra Dani Saputra dkk yang berjudul "Pengaruh motivasi belajar terhadap hasil belajar siswa SMK” dengan menggunakan analisis kuantitatif menunjukkan hasil bahwa terdapat hubungan positif dan signifikan antar kedua variabel. ${ }^{25}$

Beberapa penelitian yang penulis paparkan di atas memang hanya sebagian kecil saja, masih banyak penelitian-penelitian yang terkait dan motivasi belajar peserta didik. Penulis berharap, penelitian ini dapat mengisi kekosongan "gap" terkait literatur persoalan terkait dengan motivasi dan pembelajaran daring.

\section{Metode Penelitian}

Penelitian ini menggunakan penelitian kuantitatif dengan Analisis Mann Whitney $U$. analisis ini merupakan salah satu teknik statistik non parametrik yang digunakan untuk menguji ada tidaknya perbedaan antara variabel tergantung yang disebabkan oleh variabel bebas. Suatu data dapat dianalisis dengan menggunakan Mann Whitney $U$ jika data tidak memenuhi uji

\footnotetext{
${ }^{22}$ Siti Suprihatin, "Upaya guru dalam meningkatkan motivasi belajar siswa," Jurnal Pendidikan Ekonomi UM Metro 3, no. 1 (2015): 73-82.

23 Dewi Permata Sari dan A. R. Rusmin, "PENGARUH IKLIM KELAS TERHADAP MOTIVASI BELAJAR PESERTA DIDIK DI SMAN3 TANJUNG RAJA,” Jurnal PROFIT Kajian Pendidikan Ekonomi dan Ilmu Ekonomi 5, no. 1 (2018): 80-88.

${ }^{24}$ Itto Nesyia Nasution dan Auliya Syaf, "HUBUNGAN IKLIM KELAS TERHADAP MOTIVASI BELAJAR SISWA SMK ABDURRAB,” Psychopolytan: Jurnal Psikologi 1, no. 2 (2018): 98-110.

${ }^{25}$ Hendra Dani Saputra, Faisal Ismet, dan Andrizal Andrizal, "Pengaruh Motivasi Terhadap Hasil Belajar Siswa SMK," Invotek: Jurnal Inovasi Vokasional dan Teknologi 18, no. 1 (2018): 25-30.
} 
asumsi normalitas dan homogenitas. ${ }^{26}$ Penelitian ini ingin mengetahui motivasi belajar siswa SMA selama menggunakan sistem online atau daring, sehingga populasi dalam penelitian ini adalah seluruh siswa SMA yang menggunakan dan mengikuti proses pembelajaran dengan menggunakan sistem online atau daring. Tekhnik sampling yang digunakan yaitu accidental sampling dengan menyebarkan kuesioner motivasi belajar melalui google form dalam jangka waktu 7 hari.

Alat ukur yang digunakan pada penelitian ini adalah berupa kuesioner tertutup tentang motivasi belajar. Kuesioner motivasi belajar dibuat oleh peneliti sendiri dengan menggunakan aspek-aspek dari teori Chernis \& Goleman (2001). Kuesioner terdiri dari 8 indikator perilaku dan 18 aitem. Aitem terbagi atas dua yaitu aitem favorable dan unfavorable. Masing-masing jenis aitem terdiri dari 9 butir aitem.

Penulis menyebarkan kuesioner tentang motivasi belajar dengan menggunakan google form ke seluruh siswa SMA/SMK/MA yang ada di Indonesia. Penyebaran kuesioner ini kami lakukan selama 7 hari atau 1 minggu, dengan alasan praktis dari penulis bahwa waktu tersebut cukup untuk menyebarkan kuesioner secara merata ke seluruh siswa dan agar mendapatkan subjek dalam jumlah yang banyak.

Penyebaran kuesioner kami mulai pada tanggal 26 Mei hingga tanggal 1 Juni 2020. Dalam waktu satu minggu kami berhasil memperoleh subjek sebanyak 344 dari 21 provinsi yang ada di Indonesia yaitu Kalimantan Timur, Kalimantan Barat, Kalimantan Tengah, Kalimantan Selatan, Kalimantan Utara, Sulawesi Selatan, Sulawesi Barat, Sulawesi Tenggara, Sulawasi Utara, DKI Jakarta, Jawa Tengah, Jawa Barat, Jawa Timur, DI Yogyakarta, Banten, NTB, Bengkulu, Riau, Sumatra Selatan, Aceh dan Jayapura. Jumlah siswa laki-laki sebanyak 92 dan siswa perempuan sebanyak 252.

Pada penelitian ini kami melakukan skoring dengan menggunakan skala likert, dengan kategori jawaban sebanyak 5 yaitu Sangat Setuju (SS), Setuju (S), Ragu-ragu (R), Tidak Setuju (TS) dan Sangat Tidak Setuju (STS). Opsional tersebut dalam butir aitem favorable yaitu (SS) bernilai 5, (S) bernilai 4, (R) bernilai 3, (TS) bernilai 2 dan (STS) bernilai 1. Sedangkan dalam butir aitem unfavorable yaitu (SS) bernilai 1, (S) bernilai 2, (R) bernilai 3, (TS) bernilai 4 dan (STS) bernilai 5.

\footnotetext{
${ }^{26}$ Miftahun Ni'mah Suseno, Statistika : Teori dan Aplikasi Untuk Penelitian Ilmu Sosial dan Humaniora, 2012 (Yogyakarta: Ash-Shaff, t.t.), 80.
} 


\section{Hasil dan Pembahasan}

Sebelum membahas mengenai hasil analisis data, perlu kiranya untuk mengetahui terlebih dahulu tentang kategorisasi skor subjek. Kategorisasi dilakukan untuk menempatkan individu ke dalam kelompok-kelompok yang posisinya berjenjang menurut kontinum pada masing-masing variable. Jika berdasarkan kurve normal, peneliti biasanya membagi kategori subjek menjadi 3 atau 5 kategorisasi dengan mempertimbangkan fungsi sebaran deviasi standar dalam kurve normal. Pada penelitian ini, jenjang kategorisasi yang akan digunakan adalah 5 yaitu jenjang sangat rendah, rendah, sedang, tinggi dan sangat tinggi. Adapun rumus yang digunakan adalah sebagai berikut :

Tabel.1

Rumus Norma Kategorisasi Skor Subjek

\begin{tabular}{|c|c|}
\hline Kategori & Rumus \\
\hline Sangat Rendah & $\mathbf{X} \leq \boldsymbol{\mu}-\mathbf{1 , 8} \boldsymbol{\sigma}$ \\
\hline Rendah & $\boldsymbol{\mu}-\mathbf{1 , 8} \boldsymbol{\sigma}<\mathbf{X} \leq \boldsymbol{\mu}-\mathbf{0 , 6} \boldsymbol{\sigma}$ \\
\hline Sedang & $\boldsymbol{\mu}-\mathbf{0 , 6} \boldsymbol{\sigma}<\mathbf{X} \leq \boldsymbol{\mu}+\mathbf{0 , 6} \boldsymbol{\sigma}$ \\
\hline Tinggi & $\boldsymbol{\mu}+\mathbf{0 , 6} \boldsymbol{\sigma}<\mathbf{X} \leq \boldsymbol{\mu}+\mathbf{1 , 8} \boldsymbol{\sigma}$ \\
\hline Sangat Tinggi & $\boldsymbol{\mu}+\mathbf{1 , 8} \boldsymbol{\sigma}<\mathbf{X}$ \\
\hline
\end{tabular}

Sumber : Suseno (2012)

\section{Keterangan :}

X : Skor Total

$\sigma \quad$ : Standar Deviasi

$\mu \quad$ : Mean

Adapun hasil kategorisasi subjek adalah sebagai berikut :

Tabel. 2

Kategorisasi Skor Motivasi Belajar

\begin{tabular}{|c|c|c|c|}
\hline Kategori & Rumus & Jumlah Subjek & Persentase (\%) \\
\hline Sangat Rendah & $\mathrm{X} \leq 49$ & 10 & $2,9 \%$ \\
\hline Rendah & $49>\mathrm{X} \leq 60$ & 68 & $19,7 \%$ \\
\hline Sedang & $60>\mathrm{X} \leq 72$ & 175 & $51 \%$ \\
\hline Tinggi & $72>\mathrm{X} \leq 83$ & 79 & $22,9 \%$ \\
\hline Sangat Tinggi & $83>\mathrm{X}$ & 12 & $3,5 \%$ \\
\hline \multicolumn{2}{|r|}{ Jumlah } & $\mathbf{3 4 4}$ & $\mathbf{1 0 0} \%$ \\
\hline
\end{tabular}


Berdasarkan tabel di atas menunjukkan bahwa terdapat lima kategori subjek pada variable motivasi belajar, yaitu sangat rendah, rendah, sedang, tinggi dan sangat tinggi. Sebanyak 10 subjek dari total 344 subjek atau setara dengan 2,9\% berada pada kategori sangat rendah. Kemudian 68 subjek dari total 344 subjek atau setara dengan 19,7\% berada pada kategori rendah. Sebanyak 175 subjek dari total 344 subjek atau setara dengan $51 \%$ berada pada kategori sedang. Selanjutnya 79 subjek dari total 344 subjek atau setara dengan 22,9\% berada pada kategori tinggi. Dan 12 subjek dari total 344 subjek atau setara dengan 3,5\% berada pada kategori sangat tinggi.

Pada penelitian ini kami menganalisis data dengan menggunakan analisis non parametrik yaitu Mann Whitney $U$, karena data yang kami dapatkan tidak berdistribusi normal dan homogen. Analisis Mann Whitney $U$ merupakan teknik statistik non parametrik yang digunakan untuk menguji ada tidaknya perbedaan pada 1 variabel tergantung yang disebabkan oleh 1 variabel bebas. ${ }^{27}$ Adapun hasilnya adalah sebagai berikut :

Tabel. 3 Hasil Uji Statistik dengan Menggunakan Analisis Mann Whitney $U$

\begin{tabular}{cccc}
\hline Variabel & $\begin{array}{c}\text { Mann } \\
\text { Whitney } \boldsymbol{U}\end{array}$ & Sig. & Keterangan \\
\hline Motivasi Belajar & 8123,000 & 0,000 & $\begin{array}{c}\mathrm{p}<0,05 \\
\text { (signifikan) }\end{array}$ \\
\hline
\end{tabular}

Berdasarkan tabel di atas yang menggunakan teknik statistik non parametrik Mann Whitney $U$, diketahui bahwa nilai Mann Whitney $U$ adalah sebesar 8123,000 dan nilai signifikansi adalah sebesar 0,000 yang artinya motivasi belajar pada siswa yang mengikuti pembelajaran daring atau online di tengah situasi pandemik virus Covid-19 ini menurun, karena nilai signifikansi yaitu 0,000 adalah kurang dari 0,05 ( $\mathrm{p}<0,05)$.

Selain itu, peneliti juga menemukan adanya perbedaan motivasi belajar antara siswa lakilaki dan siswa perempuan, sebagaimana di paparkan pada tabel di bawah ini :

Tabel. 4 Perbedaan Motivasi Belajar Antara Siswa Laki-Laki Dan Perempuan

\begin{tabular}{|c|c|c|c|}
\hline Variabel & Jenis Kelamin & N & Mean Rank \\
\hline \multirow{2}{*}{$\begin{array}{c}\text { Motivasi } \\
\text { Belajar }\end{array}$} & Laki-laki & 92 & 134,79 \\
\cline { 2 - 4 } & Perempuan & 252 & 186,27 \\
\hline
\end{tabular}

\footnotetext{
${ }^{27}$ Statistika : Teori dan Aplikasi Untuk Penelitian Ilmu Sosial dan Humaniora. 80.
} 
Berdasarkan pemaparan pada tabel di atas, dapat dilihat bahwasanya siswa laki-laki yang berjumlah 92 orang memiliki nilai mean rank sebesar 134,79 dan siswa perempuan yang berjumlah 252 orang memiliki nilai mean rank sebesar 186,27. Dari hasil tersebut dapat disimpulkan bahwa moivasi belajar pada siswa perempuan lebih besar dibandingkan dengan siswa laki-laki.

Setelah dilakukan hasil uji hipotesis kepada seluruh siswa SMA yang mengikuti proses pembelajaran dengan sistem online atau daring, dengan menggunakan analisis dari Mann Whitney $U$, menunjukkan bahwa motivasi belajar pada siswa yang mengikuti pembelajaran daring atau online di tengah situasi pandemik virus Covid-19 ini menurun.

Ada beberapa faktor yang mempengaruhi menurunnya motivasi belajar pada siswa jika ditinjau secara inheren dengan situasi belajar selama masa covid-19, baik faktor internal maupun faktor eksternal. Berdasarkan data deskriptif yang diperoleh, bahwa faktor eksternal seperti kondisi lingkungan belajar memberikan pengaruh terhadap menurunnya motivasi belajar siswa. Dengan kondisi belajar yang kondusif dan mendukung, siswa akan lebih semangat dalam belajar sehingga tujuan pembelajaran yang telah ditetapkan dapat tercapai dengan efektif dan efisien.

Kondisi lingkungan belajar daring mengharuskan siswa untuk belajar di rumahnya masing-masing, guru tidak dapat mendampingi dan mendidik siswa secara langsung sehingga guru tidak dapat melalukan tindakan seperti memberi hadiah, memuji, menegur, menghukum, dan memberikan nasihat. Padahal tindakan-tindakan guru tersebut dapat menguatkan motivasi instrinsik siswa.

Data deksriptif menunjukkan bahwa dari 344 siswa 52,6\% diantaranya mengaku semangat belajarnya menurun selama pembelajaran daring. Kondisi belajar di rumah tentu berbeda dengan kondisi belajar di ruang kelas. Di rumah, siswa harus mampu untuk melakukan belajar secara mandiri dan menjaga kualitas belajarnya agar apa yang materi pembelajaran dapat dipahami dengan efektif.

Selain itu, faktor lain lain yang menyebabkan turunnya motivasi belajar siswa adalah waktu yang tepat untuk belajar. 61,1\% siswa mengaku sulit untuk menemukan waktu yang tepat untuk belajar di rumah. Lingkungan sosial keluarga yang kurang kondusif menyebabkan siswa tidak dapat fokus untuk belajar, sehingga harus ada kerja sama dan dukungan orang tua agar siswa dapat tetap belajar dengan tenang.

Motivasi belajar adalah keseluruhan daya penggerak yang ada di dalam diri siswa yang memunculkan niat untuk terus melakukan kegiatan belajar dan memberikan arah pada kegiatan 
belajar sehingga tujuan yang diinginkan itu dapat tercapai. Motivasi belajar yang tinggi dapat dilihat dari ketekunan siswa dalam menghadapi tugas yang diberikan oleh guru, memiliki sifat ulet dalam menghadapi setiap kesulitan dan juga menunjukkan minat yang sangat tinggi dalam belajar. $^{28}$

Motivasi belajar sangat penting dimiliki oleh seseorang terutama bagi siswa yang sedang menempuh pendidikan di sekolah. tinggi rendahnya motivasi belajar siswa sangat menentukan kualitas perilaku dalam mengerjakan tugas yang diberikan. ${ }^{29}$ Adanya motivasi belajar akan mendorong siswa untuk lebih bersemangat dalam belajar dan mengerjakan tugas yang diberikan oleh guru, agar supaya menghasilkan hasil yang positif dan sesuai dengan yang diinginkan.

\section{Kesimpulan}

Wabah covid-19 mengharuskan setiap kegiatan pembelajaran dilakukan dengan daring. Sehingga guru dan siswa tidak dapat bertatap muka secara langsung dalam kelas tetapi harus dengan perantara teknologi informasi. Situasi baru yang harus dihadapi siswa ini memberikan dampak pada motivasi belajar siswa. Dari hasil analisis mann whitney $\mathrm{U}$ data kuesioner dari 344 siswa SMA/SMK/MA dapat diketahui bahwa motivasi belajar siswa menurun selama pembelajaran daring.

\section{Saran}

Berdasarkan hasil penelitian, pembahasan serta kesimpulan yang telah dijelaskan sebelumnya, maka peneliti mengajukan beberapa saran. Pertama bagi subjek penelitian, peneliti mengharapkan agar para siswa SMA untuk terus meningkatkan semangatnya dalam belajar, walaupun dalam kondisi seperti ini. Mengambil hikmah dan sisi positif dari situasi yang tengah di hadapi. Kedua, bagi peneliti selanjutnya yang ingin melakukan penelitian mengenai motivasi belajar siswa di tengah situasi pandemik Covid-19, untuk menambahkan variabel-variabel yang mendukung untuk mendapatkan hasil yang lebih baik. Selain itu, mungkin alangkah lebih baiknya jika subjek penelitian di perluas lagi seperti seluruh jenjang pendidikan yang ada, dengan tujuan untuk mendapatkan hasil yang luas terkait motivasi belajar di tengah sistuasi seperti ini.

\footnotetext{
${ }^{28}$ Sadirman, Interaksi dan Motivasi Belajar Mengajar. Hlm. 84

${ }^{29}$ Sadirman. 84
} 


\section{Daftar Pustaka}

Anissa Windarti. "Impact of Corona Virus Outbreak Towards Teaching and Learning Activities In Indonesia," t.t.

Anissa Windarti, Zaharah, Galia Ildusovna Kirilova. "Impact of Corona Virus Outbreak Towards Teaching and Learning Activities In Indonesia." 2020, Jurnal Sosial dan Budaya Syar'i, 07, no. 03 (t.t.): 269-82. https://doi.org/10.15408/sjsbs.v7i3.15104.

Budi Sulaeman, dkk. "Intervensi Self Regulation Empowerment Program Untuk Meningkatkan Motivasi Berprestasi Mahasiswa Non Reguler di Jurusan X Universitas X.”Jurnal Muara Ilmu Sosial, Humaniora, dan Seni 1, no. 2 (Oktober 2017): 519-28.

Emda, Amna. "Kedudukan motivasi belajar siswa dalam pembelajaran.” Lantanida Journal 5, no. 2 (2018): 172-182.

Gowing, Marilyn K. "Measurement of Individual Emotional Competence" dalam Daniel Goleman, Cary Cherniss (ed.). The emotionally intelligent workplace: How to select for, measure, and improve emotional intelligence in individuals, groups, and organizations. (Fransisco: Jossey-Bass, 2001)

Sekretariat Kabinet Republik Indonesia. 'Kebijakan 'Social' dan 'Physical Distancing' Harus Libatkan Tokoh Sampai RT/RW." Diakses 22 April 2020. https://setkab.go.id/kebijakan-social-dan-physical-distancing-harus-libatkan-tokohsampai-rt-rw/.

Miftahun Ni'mah Suseno. Statistika: Teori dan Aplikasi Untuk Penelitian Ilmu Sosial dan Humaniora. 2012. Yogyakarta: Ash-Shaff, t.t.

"Motivasi Belajar Mahasiswa Terhadap Metode Pembelajaran Online iLearning Pada Perguruan Tinggi," t.t.

Nurhayati, Nurhasanah, Dahliana. "Dinamika Motivasi Belajar Pada Siswa Mandiri di SMPN 10 Banda Aceh.” Universitas Syiah Kuala 1, no. 2 (2016): 73-79.

Peter Salim, dan Yenny Salim. Kamus Besar Bahasa Indonesia Kontemporer. Jakarta: Modern English, 1991.

Sadirman. Interaksi dan Motivasi Belajar Mengajar. Jakarta: PT Raja Grafindo Persada, 2012. Santrock, John W. “Perkembangan Pendidikan.” Jakarta: Erlangga, 2003.

Pusdiklat Pegawai Kementerian Pendidikan dan Kebudayaan. "SURAT EDARAN MENDIKBUD NO 4 TAHUN 2020 TENTANG PELAKSANAAN KEBIJAKAN PENDIDIKAN DALAM MASA DARURAT PENYEBARAN CORONA VIRUS DISEASE (COVID- 19 ),” 24 Maret 2020. https://pusdiklat.kemdikbud.go.id/surat- 
Adhetya Cahyani, Iin Diah Listiana, Sari Puteri Deta Larasati

edaran-mendikbud-no-4-tahun-2020-tentang-pelaksanaan-kebijakan-pendidikandalam-masa-darurat-penyebaran-corona-virus-disease-covid-1-9/.

Syaiful Bahri Djamarah. Psikologi Belajar. Jakarta: Rineka CIpta, 2002.

Syarifudin. Skripsi, "Pengembangan Sistem Pembelajaran Online di SMK NU Unggaran”, (Semarang: UNNES, 2017).

Wang, H.H, Huang, R.H., Liu, D.J., Tlili, A., Yang, J.F.,. Handbook On Facilitating Flexible

Learning, During Educational Disruption: The Chinese Experience In Maintaining Undisrupted Learning in Covid-19 Outbreak. 2020 ed. Smart Learning Institute of Beijing Normal University. 